\title{
混合蛋白質へのアミノ酸補足効果〔II]
}

\section{Supplemental Effect of Amino Acids to the Mixed Protein Patterning upon Average Japanese Diet. ( II )}

\author{
日本食混合蛋白質への Threonine 補足効果に関する \\ シロネズミ実験 \\ The Effect of Supplemental Threonine to the Proteins \\ in the Japanese Diet on the Rat Nutrition.
}

(昭 和 36 年 2 月 6 日 受理)

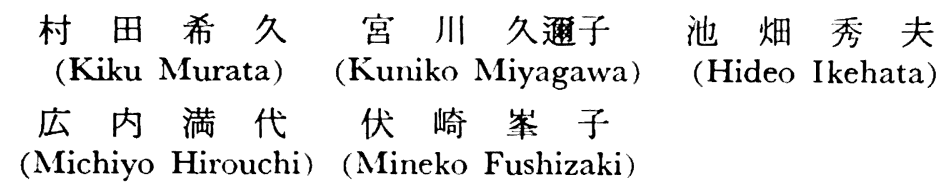

The effect of supplements of threonine, lysine, methionine and tryptophan to the proteins of the typical Japanese diet has been studied in rats. The protein mixture consisted chiefly of rice, fish-meal, wheat and soybeans (which contributed respectively $32,32,18$, and $8 \%$ of the total protein) with smaller amounts of dried milk, egg, beef and vegetable. As a basal diet, corn starch was added to give a protein level of $5 \%$, and fat, minerals and vitamins were supplied to make the original foods components except the protein level.

The results of the rat experiments indicated that the supplementation of the basal diet with $0.2 \%$ DL-threonine or $0.2 \%$ each of DL-threonine and L-lysine not only showed a marked increase of growth in rats, but also overcame the damaging effect of the mixture of $0.08 \%$ or $0.2 \%$ each of DL-methionine and DL-tryptophan.

It was observed also that $0.04 \%$ L-methionine with or without $0.02 \%$ L-tryptophan, which was supposed to be the defficient amount, stimulated some growth in rats. There was no growth stimulation with $0.08 \%$ L-methionine with or without $0.04 \%$ L-tryptophan, but the addition did not exhibit a deleterious effect like that of DL-forms.

Again, it was observed that an additional supplementation of $0.2 \%$ DL-threonine to 0.08\% L-methionine and $0.04 \%$ L-tryptophan showed a marked beneficial effect on the growth in rats.

著者らは前報1ににいて1954年度国民栄養調查結果に二 よる主な蛋白質源を配台した乾嬠饲料を窒素（以下 $\mathrm{N}$ する） $0.8 \%$ レベルとした基本飼料にてシロネズミを養 い, これに Methionine (Met) と Tryptophan (Try 添加, Lysine (Lys) 添加, Lys と Threonine (Thr) 添加の実験を行なった結果, 各 $0.2 \%$ DL-Met 上DL-Try 添加ではかえって悪影響をしめし，各 $0.04 \%$ DL-Met， DL-Try 添加群と 0.2\% L-Lys 添加群で沬無添加群上 大差は見られず，各 $0.2 \%$ L-Lys と $0.2 \%$ DL-Thr 添 加により著るしい効を認めた。

その後類似の飼料に対するこれら4種のアミノ酸の効 について更に詳紏に実験を行なった結果，本混合蛋白質 への Thr 補足効果は L-Lys との協同効果というより
Thr 単独でかなりの効を替することを認めた。また各 $0.08 \%$ もしくは $0.2 \%$ \% DL-Met, DL-Try 添加は前回

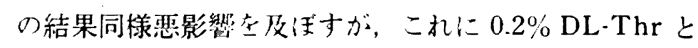
L-Lys もしくは 0.2\% DL-Thr のみ在補足添加する時 は枣影響仗完全に打消きれるのみでなく，02\%DL-Thr のみ上り幾分良好な結果を得た。

一方 DL-体の代りに L- 体の Met や Try を用い た場合は $0.08 \%$ 添加でも害をしめさず， $0.04 \%$ L-Met 添加では僅かではあるが効果さえ示めした。更にこれに $0.2 \% \mathrm{DL}$ - Thr を補足する時は同じく著るしい効をしめ した。

以下実験結果を報告する。 


\section{実験方 法}

1 実験動物……S D 系シロネズミ雄を用い1群 6 匹宛 とし，実験 I， II，IIIの雨均㑬物体重は各 $66,74,62 \mathrm{~g}$ であった、

2 飼育期間……奏験 I， II， III 飼育期間は各 38,34 , 39日である。

3 飼料……1957年度国民栄調查秥果に淮して各主要 食品を Table I にしめすように配合した。各食品より 由来する蛋白钼の配合も Table I に示めすようである。 これは N $2.1 \%$ なのでコンタターチで N $0.8 \%$ (蛋回筫 $5 \%$ ）にし，マッカラム塩：ショートニングを加えて無 㙨塩類，脂肪を元のしハル，即ち $2.1 \%$ 上 $3.2 \%$ に補正 したもの基本飼料とした、

上記の飼料に含末机る必須了ミ，酸い䍊储上分析值
は TableII にしめすようである。

また飼料を与える時は之に補足アミノ酸ならびにビタ ミン混液を前報1)にしめすように加え，添加アミノ酸に よるNレベルの相異は L-Glutamine (Glu)によって同 一レベルに補正した。

飼料は毎日自由食で与え，1日掑取量を明らかにした。 4 体重……1 週間毎に体重を測定し, 各群の平均値を 求めた。

5 蛩白钼効率比……毎日の飼料控取量を明らかにした 上, 各群の 1 週間の平均拱取最を求め, その蛋白澌量に 对する体重增加睹の比を蛋白質効率比とした。

6 肝 Xanthine Oxidase 活性 (肝XOA) 測定……旬 蒿試験終了後, ネズミ文断頭して直らに肝满を取り出し 目方を䚵り，前報1にしめす方法でXOA を測定した。

Table I Composition of the Mixed Diet

\begin{tabular}{|c|c|c|c|c|}
\hline \multirow{2}{*}{ Constituent } & \multirow{2}{*}{$\begin{array}{c}\text { Amount } \\
0\end{array}$} & \multirow{2}{*}{ o of Total protein } & \multicolumn{2}{|c|}{$\mathrm{g}$ Protein $/ 100 \mathrm{~g}$ Diet } \\
\hline & & & Original diet & Diluted diet \\
\hline Rice & 60 & 32 & 4.2 & 1.6 \\
\hline Wheat & 23 & 18 & 2.3 & 0.9 \\
\hline Potatoes & 4 & 2 & 0.3 & 0.1 \\
\hline Soybeans defatted, & 3 & 8 & 1.0 & 0.4 \\
\hline Fish meal & 6 & 32 & 4.2 & 1.6 \\
\hline $\begin{array}{l}\text { Dried milk, Egg, } \\
\text { Beef, Vegetables }\end{array}$ & 2 & 8 & 1.0 & 0.4 \\
\hline Oil & 2 & - & - & - \\
\hline Total Diet & - & - & 13.0 & 5.0 \\
\hline
\end{tabular}

Based on the results of the National Nutritinoal Census (1957) of food intakes by people in Japan

Table II Essential Amino Acid Composition of the Average Japanese Diet and Provisional Protein (F.A.O.)

\begin{tabular}{|c|c|c|c|c|c|c|}
\hline Amino acids & & $\begin{array}{l}\text { Estimated } \\
\text { value of } \\
\text { the mixed } \\
\text { diet }\end{array}$ & $\begin{array}{l}\qquad \text { g Amino } \\
\text { Calculated } \\
\text { value of } \\
\text { the average } \\
\text { Japanese } \\
\text { diet (II) }\end{array}$ & $\begin{array}{l}\text { Acid/g } N \\
\text { Provisional } \\
\text { protein (I) }\end{array}$ & (II) $-($ I $)$ & $\begin{array}{l}\text { Calculated } \\
\text { amounts to } \\
\text { be added to } \\
\text { diet } \\
(0.8 \mathrm{gN} / 100 \mathrm{~g}) \\
\%\end{array}$ \\
\hline Leucine & 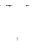 & 0.456 & 0.417 & 0.306 & +0.111 & - \\
\hline Isoleucine & & 0.333 & 0.289 & 0.270 & +0.019 & - \\
\hline Threonine & & 0.221 & 0.230 & 0.180 & $+\quad 0050$ & - \\
\hline Methionine & & 0.123 & 0.137 & 0.144 & -0.007 & - \\
\hline Total S-AA & 1 & 0.183 & 0.225 & 0.270 & -0.045 & 0.04 \\
\hline Lysine & & 0.500 & 0.334 & 0.270 & $+\quad 0.064$ & - \\
\hline Phenylalanine & & 0.302 & 0.265 & 0.180 & $+\quad 0.085$ & - \\
\hline Valine & & 0.338 & 0.331 & 0.270 & +0.061 & - \\
\hline Tryptophan & & 0.054 & 0.066 & 0.090 & -0.024 & $* 0.02$ \\
\hline
\end{tabular}

* L-Tryptophan $(=0.04$ DL-Tryptophan $)$ 


\section{実 験 結 果}

\section{実験 I}

混合蛋白倎基本飼料への $0.2 \% \mathrm{~L}$-Lys 添加， $0.2 \% \mathrm{DL}$ Thr 添加ならびに各 0.2\%L-Lys, DL-Thr の同時添加 によるネズミの体重増加曲線は Fig.I にしめすようで， 前報1) に得た結果と同しく 0.2L-Lys 添加ではごく僅か

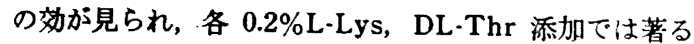
しい生長をしめした。また $0.2 \% \mathrm{DL}-\mathrm{Thr}$ 単独投与でも かなりの効を奏するこ上が本実験ならびに実験 几におい て観察され，蛋白犋効率比においても Table III 汇しめ すように，体重増加比と類似の関倸にあることが見られ た。

\section{Fig I}

Expt. (I) Gain in Weight of Rats Fed on the Mixed Diet Supplemented with Amino Acids.

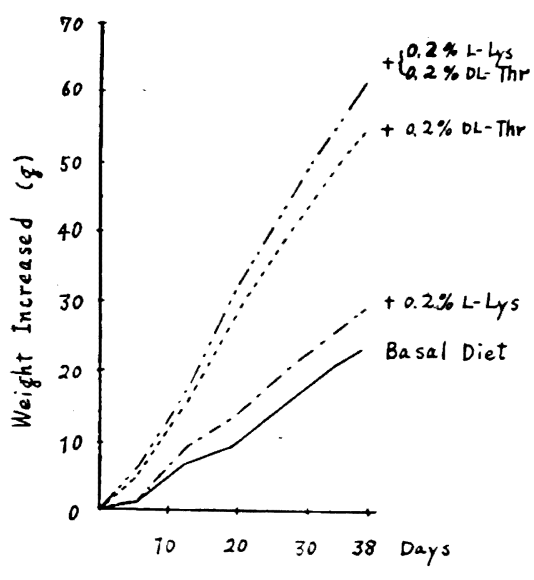

Table III Summary of Results of Experiment (I)

\begin{tabular}{l|ccc|c}
\hline & $\begin{array}{l}\text { Basal } \\
\text { diet }\end{array}$ & $\begin{array}{c}+0.2 \% \\
\text { L-Lys }\end{array}$ & $\begin{array}{c}+0.2 \% \\
\text { DL-Thr }\end{array}$ & $+\left\{\begin{array}{l}0.2 \% \text { L-Lys } \\
0.2 \% \text { DL-Thr }\end{array}\right.$ \\
\hline $\begin{array}{l}\text { Relative } \\
\text { increase } \\
\text { in weight }\end{array}$ & 1 & 1.3 & 2.4 & 2.7 \\
$\begin{array}{l}\text { Protein } \\
\text { efficiency } \\
\text { ratio }\end{array}$ & 1 & 1.2 & 1.7 & 1.7 \\
\hline
\end{tabular}

\section{実験 II}

基本飼料へ各種つミ，酸在補足した 8 群の飼育試験に よる体重曲線を Fig. II に分け一しいす。この图からも 明らかなように各 0.08\% DL-Nlet 上 DL-Try 添加群, 各 $02 \%$ DL-Met 上 DL-Try 蒸加群では基本食より体 重增加に著るしく少门，蛋白質効深比上肝 XOAについ

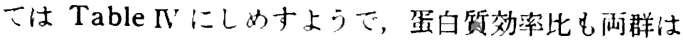
基本食群よりも劣るこ上が観察された。これら両群に $0.2 \% \mathrm{DL}$-Thr 在添加した場合，ならびに各 $0.08 \%$ DL・ Met と DL-Try 群に $0.2 \%$ DL-Thr と L-Lys を添加 した場合上もにこれらの添加こ上って体重增加, 蛋白 質効率比共にかなり上㫒し，DL-Met や DL-Try の害 が完全に打消されてしまっただけでなく，むしろ $0.2 \%$ DL-Thr と L-Lys 添加群や $0.2 \%$ DL-Thr 単独投与群 より幾分良い傾向をしめした。

\section{実験 III

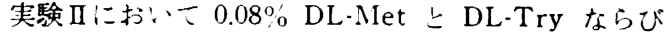 : $0.2 \% \mathrm{DL}$-Met 上 DL-Try 添加することによって悪影響をしかしたが, MetとTry : Table IIにもしめしたよう泀，飼料中の MetやTry}

Fig II

Expt. (II) Gain in Weight of Rats Fed on the Mixed Diet Supplemented with Amino Acids.

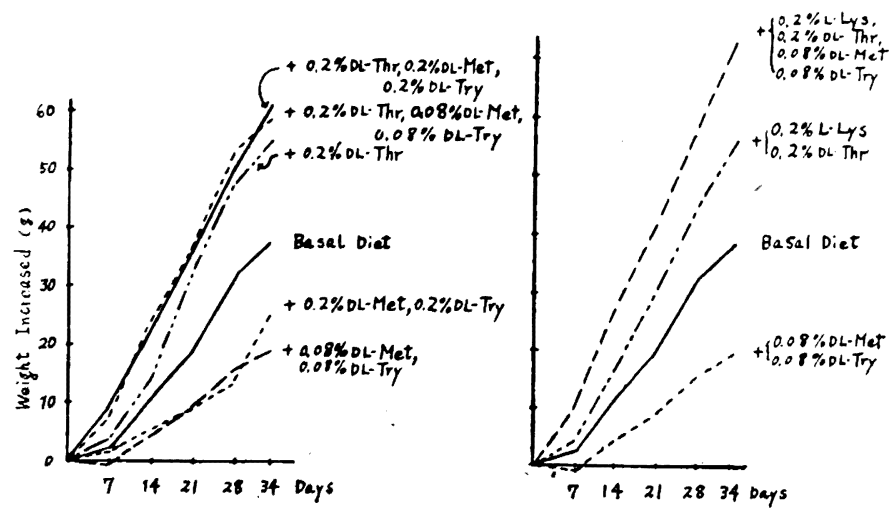


Table IV Summary of Results of Experiment (II)

\begin{tabular}{|c|c|c|c|c|c|c|}
\hline$\ldots$ & $\begin{array}{l}\text { (1) } \\
\text { Basal } \\
\text { Diet }\end{array}$ & $+0.2^{\circ} \% \mathrm{DL}-\mathrm{Thr}$ & $+\left\{\begin{array}{l}0.08 \% \mathrm{DL}-\mathrm{Met} \\
0.08 \% \mathrm{DL}-\text { Try }\end{array}\right.$ & $+\left\{\begin{array}{l}0.08 \% \text { DL-Met } \\
0.08 \% \mathrm{DL}-\mathrm{Try} \\
0.20 \% \mathrm{DL}-\mathrm{Thr}\end{array}\right.$ & $+\left\{\begin{array}{l}0.2 \% \text { DL-Met } \\
0.2 \% \text { DL-Try }\end{array}\right.$ & $+\left\{\begin{array}{l}0.2 \% \mathrm{DL}-\mathrm{Met} \\
0.2 \% \mathrm{DL}-\mathrm{Tr}_{\mathrm{r}} \\
0.2 \% \mathrm{DL}-\mathrm{Thr}\end{array}\right.$ \\
\hline $\begin{array}{l}\text { Relative } \\
\text { increase } \\
\text { in weight }\end{array}$ & 1 & * 15 & 0.5 & * 1.6 & 0.7 & * 1.6 \\
\hline $\begin{array}{l}\text { Protein } \\
\text { efficiency } \\
\text { ratio }\end{array}$ & 2.0 & * 2.3 & 1.3 & * 2.5 & 1.7 & * 2.6 \\
\hline $\begin{array}{l}\text { Xanthine } \\
\text { oxidase } \\
\text { activity } \\
\text { in liver } \\
\mathrm{O}_{2, \ell l} / \mathrm{hr} / \mathrm{g}\end{array}$ & 56.9 & *62.0 & 55.9 & $* 64.3$ & 58.2 & 58.7 \\
\hline
\end{tabular}

* Significant differences from (1) are yes

の計算优と Provisional protein を比較しても, 飼料 あたり Met $0.04 \%$ 。，Try 0.02\% 不足の勘定になる。そ こでこれら不足是をそれぞれ L-体で別ヶに与えた場合 ( 5 群上 3 群)，両者を同時に与えた場合（7群），これ らの倍量 $0.08 \%$ L-Met と $0.04 \%$ L-Try を别々に与え た場合（6群と 4 群）上両者在同時に与えた場合 ( 8 群) について試験した結果は Fig.III（2図に分けて示めす）
ならびに Table V にしめすようで，何れにおいても 奏験【におけるような害は全く見られず，0.04\% L-Met 添加群（第 5 群）と $0.04 \%$ L-Met， $0.02 \%$ L-Try 添加 群 (第 7 群) では幾分補足効果をあらわした。

また DL-体を用いても各 $0.04 \%$ 程度 (第 2 群)な らば実験 IIにおける DL-体 $0.08 \%$ 添加の場合のよう

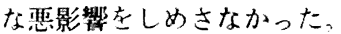

Fig III

Expt III Gain in Weight of Rats Fed on the Mixed Diet Supplemented with Amino Acids.
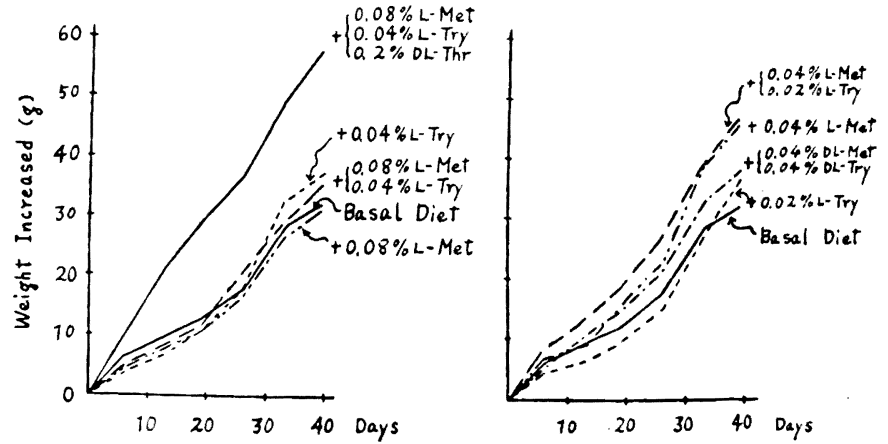

Table $V$ Summary of Results of Experiment (III)

\begin{tabular}{|c|c|c|c|c|c|c|c|c|}
\hline & $\begin{array}{l}\text { (1) } \\
\text { Basal } \\
\text { diet }\end{array}$ & $\begin{array}{l}\text { +0.04\% } \\
\text { L-Met }\end{array}$ & $\begin{array}{c}+008 \% \\
\text { L.Met }\end{array}$ & $+\left\{\begin{array}{l}0.04 \% \text { L-Met } \\
002 \% \text { L-Try }\end{array}\right.$ & $+\left\{\begin{array}{l}0.08 \% \text { L-Met } \\
0.04 \% \text { L Try }\end{array}\right.$ & $+\left\{\begin{array}{l}0.08 \% \text { L-Met } \\
0.04 \% \text { L-Try } \\
0.20 \% \text { L-Thr }\end{array}\right.$ & $\begin{array}{c}+0.02 \% \\
\text { L-Try }\end{array}$ & $\begin{array}{l}+0.04 \% \\
\text { L-Try }\end{array}$ \\
\hline $\begin{array}{l}\text { Relative } \\
\text { increase } \\
\text { in weight }\end{array}$ & 1 & * 1.4 & $\begin{array}{r}1.0 \\
\end{array}$ & * 1.4 & 1.1 & * 1.8 & 1.1 & 1.2 \\
\hline $\begin{array}{l}\text { Protein } \\
\text { efficiency } \\
\text { ratio }\end{array}$ & 1.7 & $* 21$ & 1.5 & $* 2.1$ & 1.8 & * 2.2 & 1.9 & 1.8 \\
\hline
\end{tabular}

* Significant differences from (1) are yes. 
尚本実験においても $0.2 \% D L-T h r$ の同時添加は動物 の成長に対しても蛋白愋效率に沶いても著るしい好影響 をしめした。

\section{考察}

日本食混合蛋白倎乾燥飼料を N $0.8 \%$ レベル上して シロネズミを養う時は, 同一レベルのカゼイン食に比し かなり劣ることは前報》で報告した、またこの場合に $0.2 \%$ DL-Thr と L-Lys を添加する時は著るしくジ ネズミの生長を促進する事実を認めたが，今回の実験に おいてこの成長促進は $0.2 \%$ DL-Thr 単独添加でもかな り効がある許りでなく，DL-Thr は各 $0.08 \%$ もしくは $0.2 \%$ の DL-Met と DL-Try 添加の害孛打消す働きの あることを明らかにした。

一方 DL- 体の Met や Try は多少過剩でもシロネ ズミの生長に悪影辢をおよほすが，L体では $0.08 \% \mathrm{Met}$ ， 0.04\% Try でその害は見られなかった。これらL体と DL 体の動物におよぼす影響については従来多くの研究 があるが，実験条件や投与量によってかなりその利用度 を異にする故, この点については将来研究を要する問題 であるが，Met と Try の有効量の限界はかなり狭い もののようである。

尚 $\mathrm{Thr}$ が本混合蛋白質铝料に対して著るしい補足効 果をしめす理由については明らかでないか，低蛋白質飼 料に対する栄養增進 2 ならびに植物蛋白質を多く含む飼 料への補足了ミノ酸として特異的な役割立果たすもので はないかと考えられる。

また本実験はシロネズミによる成長実駼結果であるか ら，植物蛋白質を多く撜取する人の栄美に対して Thr 投与がどの程度その蛋白質栄美値の改良, 増淮に役立つ かについても今後の研究に待たなければならない：

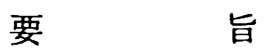

1957年度国民栄美調查結果にあらわれた食品群を配合 し，主な食品から由来する蛋白質の割合が米から $32 \%$ ， 魚から $32 \%$, 麦から $18 \%$, 大豆から $8 \%$ その他から $10 \%$ という様な混合蛋白質の飼料について，そのNレベルを
$0.8 \%$ になるようコンスターチでうすめ，無機塩類と脂 肪は元の乾燥飼料と同しくなるように補正したものを基 本飼料とし，三回にわたるシロネズミ飼有試験により， L-Lys，DL-Thr，DLもしくはL体の Met とTryな どの補足効果についてこれれら添加レベルや組合せを 変えて実験を行なった。その結果，この基本飼料への $0.2 \% \mathrm{DL} \cdot \mathrm{Thr}$ 单独添加はシロネズミの成長その他にか なり著るしい効をしめし，その効は $0.2 \% \mathrm{~L}$-Lys 同時 添加により更に幾分增強された許りでなく，各 $0.08 \%$ も しくは $0.2 \%$ の DL-Met とDL-Try 補足により見られ た悪影響は $0.2 \%$ DL-Thr の同時添加もしくは各 $0.2 \%$ DL-Thr，L-Lys の同時添加によって打消され，更に動 物の成長に対して優れた結果を与えた。

また $0.08 \%$ DL-Met や DL-Try の害はL体の Met やTry では認められず，計算上不足すると考えられる 量の各 $0.04 \% \mathrm{DL}$-Met と DL-Try $(0.04 \% \mathrm{~L}$-Met, 0.02 $\%$ L-Try 相当量)でも害は見られなかった許りでなく。 $0.04 \%$ L-Met 添加は幾分補足効果をしめした。尚本実 験において多少レベルを增した $0.08 \%$ L-Met， $0.04 \%$ L-Try の添加で見られなかった効果が，これに更に 0.2 \% DL-Thr を補足することによって協同の効果が明ら かにあらわれた。

本実験に用いた飼育動物ならびにビタミン類とアミノ 酸をご提供下され，また種々ご教授をいただいた武田研 究所に対し, 又必須了ミ, 酸研究委員会委員島苗教授に 対し深謝の意を表す。

（要旨の1 部は第 14 回栄養食糧学会総会ジポジっム に, 1 部は第 5 回国際栄養学会 (於 Washington D.C.) において発表)

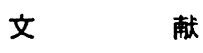

1) 村田希久 宮川久遇子池畑秀夫 松川说子 白砂 㟉子，岡照幸；本誌，11，115（1958）

2）村田希久 宮川久用子 池畑秀夫 大塚久美子； 本誌, 12, 159 (1959)

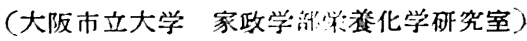

